\title{
Studies in Permeability.
}

\section{The Exosmosis of Electrolytes as a Criterion of Antagonistic Ion-Action.}

BY

\author{
WALTER STILES
}

\author{
AND \\ INGVAR JØRGENSEN. \\ With fourteen Figures in the Text.
} $\mathrm{OR}$ a considerable time now attention has been directed to the subject
of antagonistic ion-action in the absorption of substances by plants, and a number of workers have employed different methods for the investigation of the question. Yet it becomes manifest, on reviewing the literature of the subject (24), that the methods employed are generally long and laborious, while the accuracy or general character of the results obtained is open to much criticism. This is especially true of the most favoured group of methods where the use of water-cultures is involved. The notorious variability of plants growing in water-cultures, which necessitates the determination of the degree of accuracy of the results of the experiments (22), has never been taken into account in these researches, and so the correctness of the results is often very doubtful. The most interesting contribution to the subject from a theoretical point of view is that of Szuics (25), but his method, dependent upon the geotropic reaction of the seedling root and hypocotyl, although ingenious, is very laborious, and, as his results show, is not open to any great accuracy unless so many plants are under observation that the experiments become more laborious still.

Osterhout, in introducing a method from physical chemistry in the use of electrical conductivity properties of plant tissue (15), made the method of attack easier. So far, however, the use of physico-chemical methods has been very limited, and in consequence very few aspects of the problem have been considered, and little analysis of what constitutes antagonism has been attempted.

[Annals of Botany, Vol. XXIX. No. CXV. July, 1915.] 
In this connexion it is of importance to compare the researches on antagonism of those workers who have attempted to obtain quantitative data. Although qualitatively antagonism is generally regarded as the hindrance of the entrance into the plant, or through the plasma membrane, of one ion by another ion of the same sign, yet when quantitative results are attempted it is clear that different workers have been measuring different things. Thus Osterhout $(18,19,20)$ attempts to measure antagonism between two metallic ions by finding what strength of solution of salts of the two metals are equally toxic, and then mixing these two solutions in various proportions. If then each ion of either metal was as toxic in the mixed solution as in the pure solution, it should follow that all such mixed solutions would be equally toxic. It is found in certain cases that as a matter of fact this is not so, and that the mixed solutions allow of better growth than the pure solutions. The increase of growth, as compared with the growth in the pure solution, is regarded by Osterhout as a measure of the antagonism, which is greatest for one particular ratio of the antagonizing ions, and becomes less as either of the two ions becomes more concentrated at the expense of the other.

On the other hand, Szuics and some other writers have kept the quantity of one ion (the poisonous ion) constant, and have added various quantities of the other (the depoisoning ion). If the latter is much less toxic than the former, increase in the depoisoning ion reduces the toxicity of the poisonous one. This action is explained by Szücs as due to the hindrance of the entrance of one ion owing to the presence of the other. When only one ion is present the whole of the absorbing part of the plasma membrane is available for its passage, but when another ion is present a certain proportion of the absorbing part of the membrane will be used by the second ion. Hence, if this is a relatively harmless ion in comparison with the first, the more of the second ion that is present, the less of the more harmful ion will go in, so that within limits the more of the second ion that is added the greater the depoisoning. Above a certain concentration, however, the depoisoning ion will itself exert an injurious action.

In this way Szuics explains the antagonistic action of aluminium and copper. Now it will be observed at once that in this way of regarding antagonism, no antagonism is to be expected in the mixtures employed by Osterhout. The antagonism between copper and aluminium on the one hand, and that between 'nutrient' metals on the other, seem therefore to be different phenomena.

It thus seems that although Loeb's idea of antagonism was a great advance, it appears to have produced a mechanical way of regarding as one definite phenomenon all the observed cases, whereas it may be due to different underlying causes in different instances (cf. Hawkins (6)). 
For the sake of simplicity we may consider the system with which we have to deal, as consisting of the three following phases :

\begin{tabular}{c|c|c}
$\begin{array}{c}\text { Exterior } \\
\text { solution }\end{array}$ & $\begin{array}{c}\text { Complex of colloidal } \\
\text { substances (membrane) }\end{array}$ & $\begin{array}{c}\text { Interior of the cell } \\
\text { (crystalloids + colloids). }\end{array}$
\end{tabular}

But the system may be much more complex; for instance, although earlier the cell-wall was not supposed to be active in permeability phenomena, the recent investigations of Hansteen Cranner (5) suggest that this forms an essential part in the mechanism of exchange between the exterior and interior of the cell.

Now the problems of antagonism and absorption in general resolve themselves into considerations of the kinetics of this system; but of the condition of equilibrium between any two phases we know very little in any single case.

Osterhout's method of attacking the problems consists in examining tissue of a marine Alga, Laminaria saccharina, in various solutions having an electrical conductivity equal to that of sea-water. The conductivity of the tissue he regards as a measure of its permeability $(17,21)$. But the quantity which Osterhout calls the conductivity of the tissue, is really a complex quantity to which all the three phases mentioned above contribute. Höber $(7,8)$ has pointed out that conductivity, as measured by Kohlrausch's method, gives no true idea of the ion concentration of such a system, as the inner phase only contributes to a slight extent to the total conductivity. When the conductivity increases in Osterhout's experiments, he considers the increase to be due to the higher penetrating power of the ions owing to a change in permeability, but he neglects the necessary effect of this, the diffusion of electrolytes between the inner and external phases of the system. ${ }^{1}$ We have elsewhere (23) pointed out the complex character of plant tissue in regard to electrical conductivity, and that a change of conductivity may be due to a variety of different causes. ${ }^{2}$

Osterhout's method, moreover, in its present form, is applicable to so very few cases, adapted as it is to marine Algae only. In the case of higher plants difficulty arises on account of morphological structure-in many plant organs there are different forms of cells which quite possibly have different permeability properties. Thus in the stem an increase in conductivity of the tissue might be due to an increase in concentration of electrolytes in the vessels and tracheides, and have nothing to do, at any rate directly, with permeability of living cells. Also when fairly uniform

1 Osterhout has never made clear what he regards as the actual changes taking place in his experiments, but he seems definitely to regard as incorrect the view that it is diffusion phenomena which are the cause of his results.

${ }^{2}$ It is interesting to note that systems of this kind have been examined by a different method by Beutner and Loeb $(1,2,3,10,11,12)$ by measuring the electromotive forces manifested. But even if the bearing of this work to our subject is still somewhat obscure, it may prove of importance in investigations of absorption and permeability. 
tissue is used, as for example, potato tuber, if the tissue is immersed in a weak solution exosmosis takes place from the living cells, and so reduces the conductivity of the cell-sap, while in a strong solution we may expect absorption. Hence changes in conductivity of living tissue in such a case as this would depend very largely on the concentration of the external solution.

Again, where higher plants are concerned, none of the methods in use have to do with the extremely dilute solutions such as one is concerned with in the actual soil solution absorbed by higher plants. Osterhout has suggested that calcium in the soil is useful to the plant in antagonizing the harmful effect of other salts (16), but, as he himself points out elsewhere (14), below a certain concentration none of the ordinary 'nutrient' ions are poisonous, and in the soil these ions are present in extremely dilute solution (Cameron, 4).

In the present paper an account is given of a contribution towards an analysis of the action of salts on plant cells, in which we deal chiefly with the relations between the external solution and the exosmosis of electrolytes.

We do not intend to apply the results obtained to any interpretation of the functions or the structure of the plasma membrane, but to give an idea of the complexity of the problems involved, and to advocate the use of the methods of physical chemistry.

In using the methods of physical chemistry, one can get a better idea of the kinetics of the actions involved, than in the ordinary methods in general use in botanical and agricultural operations, and there is more hope of getting light shed on the complexity of the processes, but it is most necessary to beware of assuming results mechanically in all cases because a line of argument appears correct in one case. Examples of this we shall present in the part dealing with the results of experiments.

\section{METHODS.}

We have attempted, in these experiments, to obtain some idea of the relations existing between plant tissue and a solution surrounding it, by examination of the changes in electrical conductivity of the latter. If a substance is absorbed from its solution by plant tissue without producing any change in the plasma membrane, it is to be expected that the electrical conductivity of the solution will be lowered, while if the plasma-membrane is altered by the substance in such a way that its permeability to electrolytes is increased, a more rapid diffusion out from the cells into the solution may be expected, and if the concentration of the external solution is low, compared with that of the electrolytes in the cell-sap, the conductivity may be expected to rise. 
The tissue used in these experiments consisted of discs of potato tuber (Solanum tuberosum, var. King Edward VII). Potato was selected as it yields a very uniform tissue. Discs were cut having a diameter of a centimetre and a weight of about $\frac{1}{2}$ grm. Twenty of such discs were washed in distilled water, dried on filter-paper, placed in 100 c.c. of solution in a stoppered bottle, and the electrical conductivity of the solution was measured from time to time by Kohlrausch's method. As different sets of tissue vary somewhat, the experiments with potato were done in duplicate; this gave an approximation to accuracy near enough for our purpose.

In some cases living plants of bean (Vicia Faba) were used. They were grown in water-culture for some time in order that plants might be obtained with uninjured roots. Plants with as equal a root development as possible were then selected, and each one placed with its roots immersed in Ioo c.c. of solution, and the conductivity of this measured as before. With careful selection of equally developed plants it was found that duplicating the experiments yielded results of sufficient accuracy. The curves which follow were plotted from these results, the increase in the electrical conductivity being taken as ordinates, and the time as abscissae.

The preliminary measurements were made in the Department of Physical Chemistry of this University. We would thank Dr. H. M. Dawson for putting at our disposal the resources of his laboratory.

\section{EXPERIMENTS.}

Series I. In this series various substances were used as external medium in a concentration of $\frac{\mathrm{N}}{1000}$. The substances employed comprised both undoubted poisonous substances and salts of nutritive metals. The following substances were used :

Copper sulphate 'Kahlbaum, with certificate of guarantee'
Mercuric chloride " " "
Quinine hydrochloride 'Kahlbaum"
Calcium chloride 'Kahlbaum, with certificate of guarantee'
Sodium chloride " " " " " "
Magnesium chloride
Potassium chloride
Aluminium chloride 'Kahlbaum'."

As the accompanying curves show, in all these cases exosmosis of the electrolytes in the cell-sap takes place, as indicated by a very definite rise in the electrical conductivity. This rise is on a much greater scale in the case of undoubted toxic substances, than in the case of salts of nutrient metals. The obvious explanation is that the toxicity of the poisonous 
metal ions is due to the formation of substances in the plasma membrane which have much greater permeability than the original compounds they replace, with the result that a much greater rate of exosmosis of electrolytes from the cell takes place. It has to be remembered that what we are measuring is the difference between absorption and excretion. It is not therefore altogether safe to take the increase in conductivity as a measure

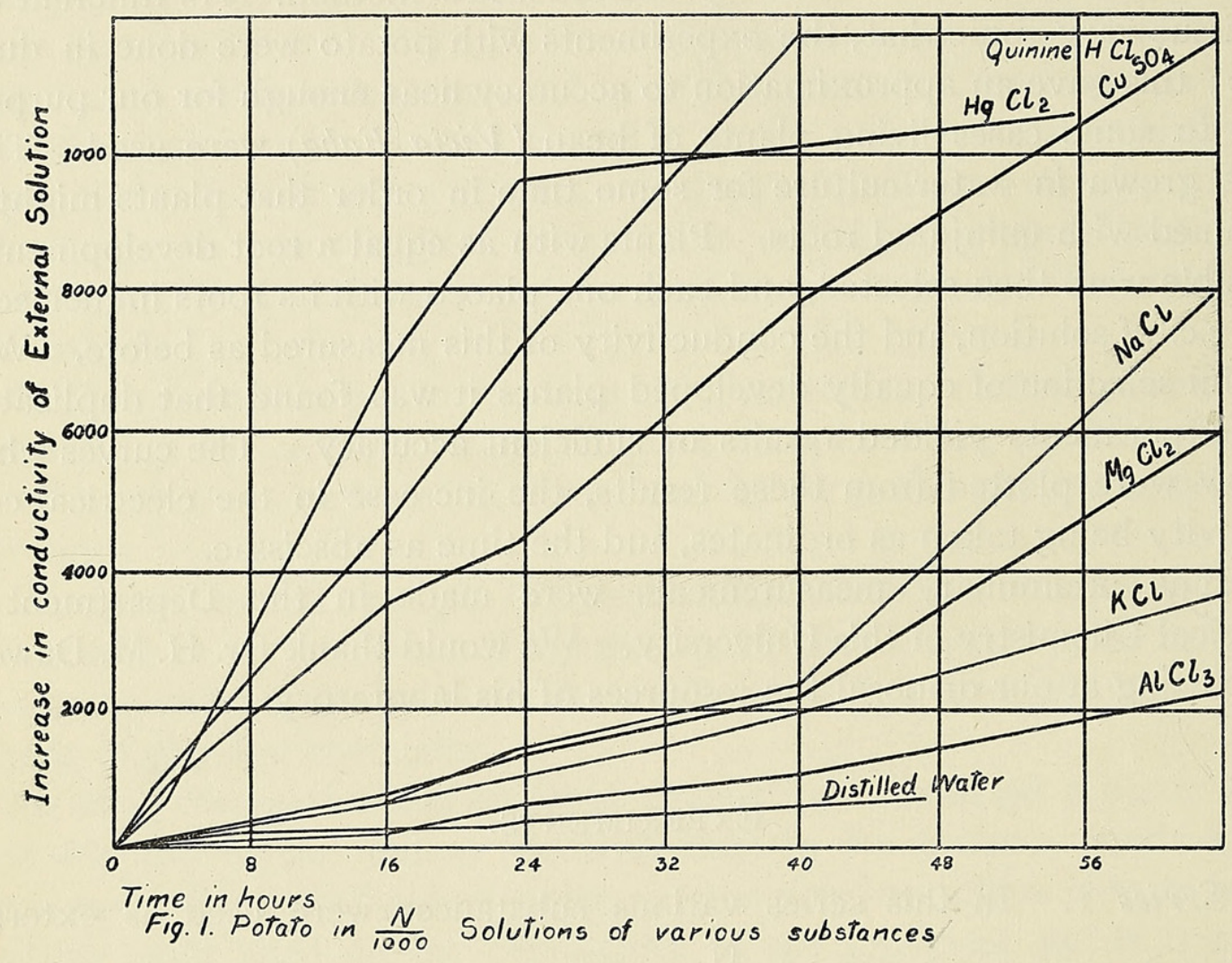

of diffusion out from the cell, or as a measure of the toxicity of the surrounding solution.

Series 2. In this series the change in the conductivity of the external solutions was investigated for solutions of one substance in different concentrations. Copper sulphate, as in Series I, was used in the following concentrations : $\frac{\mathrm{N}}{\mathrm{I} 25} ; \frac{\mathrm{N}}{250} ; \frac{\mathrm{N}}{500} ; \frac{\mathrm{N}}{1000} ; \frac{\mathrm{N}}{2000} ; \frac{\mathrm{N}}{5000}$. The accompanying curves show very clearly how the increase in conductivity, and consequently the increase in the number of ions present, is dependent on the strength of the solution. From $\frac{\mathrm{N}}{5000}$ to $\frac{\mathrm{N}}{250}$ there is a definite increase in exosmosis, with increasing concentration of copper sulphate. $\frac{\mathrm{N}}{\mathrm{I} 25}$ gives actually slightly less increase of conductivity than $\frac{\mathrm{N}}{25^{\circ}}$, although this difference may be within the limits of experimental error. 
Stiles and Forgensen.-Studies in Permeability. I. 355

It will be observed that osmotic pressure alone cannot account for the result, as from this point of view the greatest exosmosis would be expected in the case of the weakest solution.

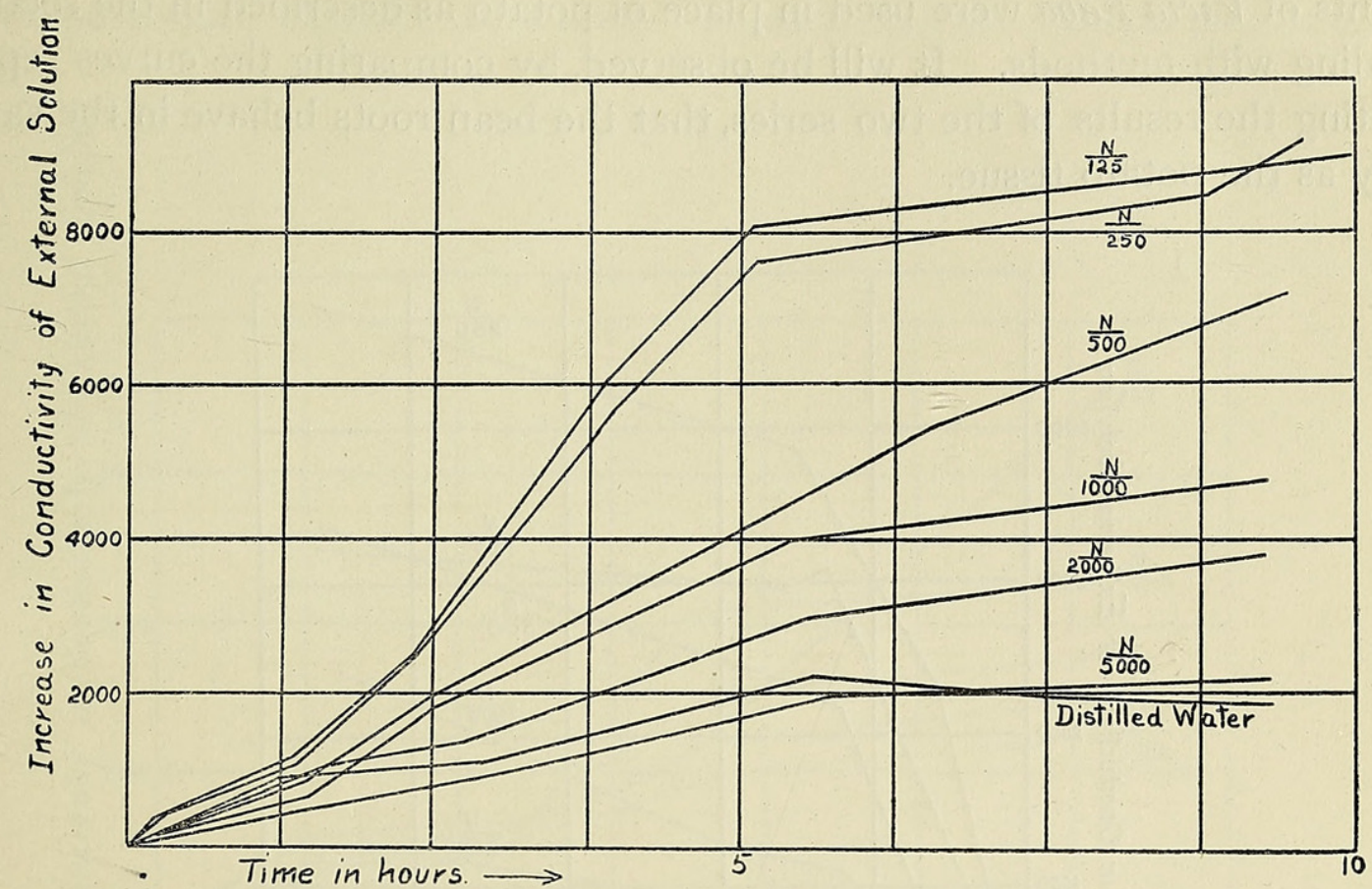

Fig. 2a. Potato in Copper sulphate solutions of various strengths

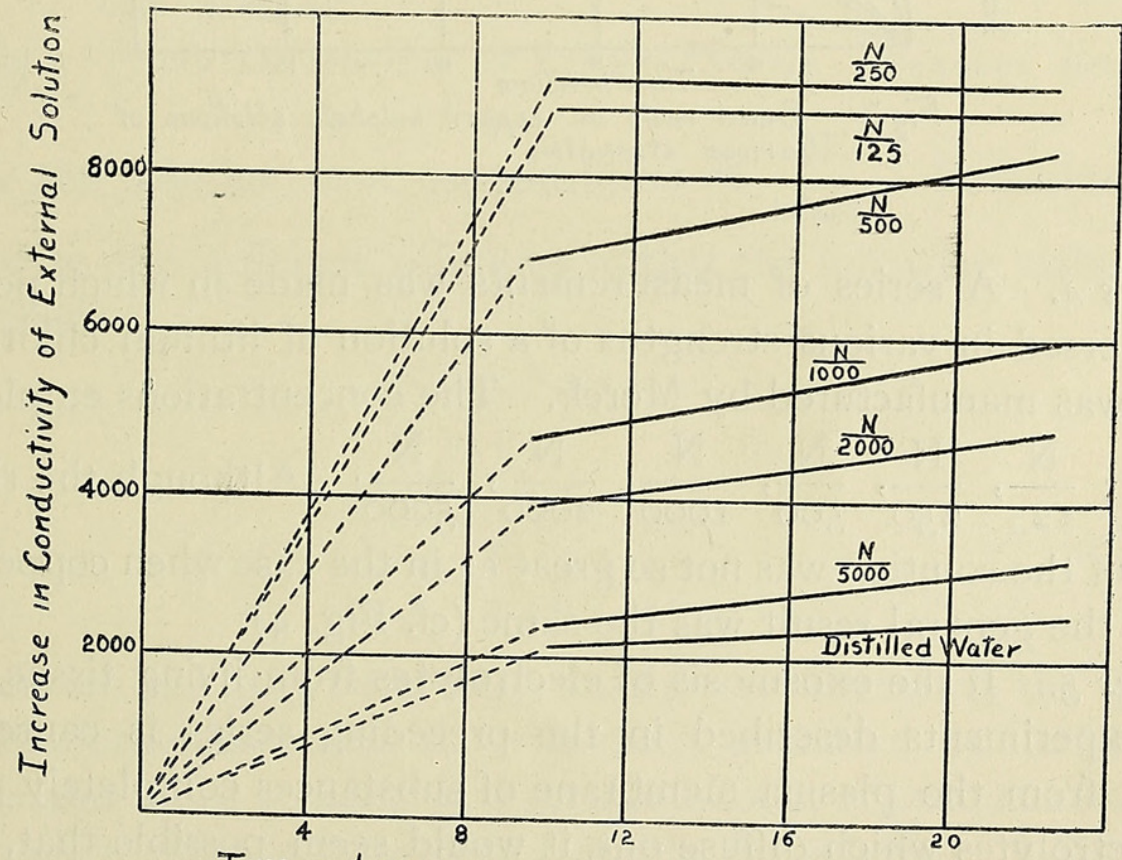

Fig. $2 b$. The Same curves continued for a longer time

It seems in this case definite enough, that the greater the number of poisonous ions in the solution, the more rapid the exosmosis, or, put in other words, the more rapidly the plasma membrane is rendered more permeable. 
Series 3. In this series copper sulphate was again used as the external solution, and various strengths between $\frac{\mathrm{N}}{\mathrm{I} 25}$ and $\frac{\mathrm{N}}{5000}$ were employed. Living plants of Vicia Faba were used in place of potato as described in the section dealing with methods. It will be observed, by comparing the curves representing the results of the two series, that the bean roots behave in the same way as the potato tissue.

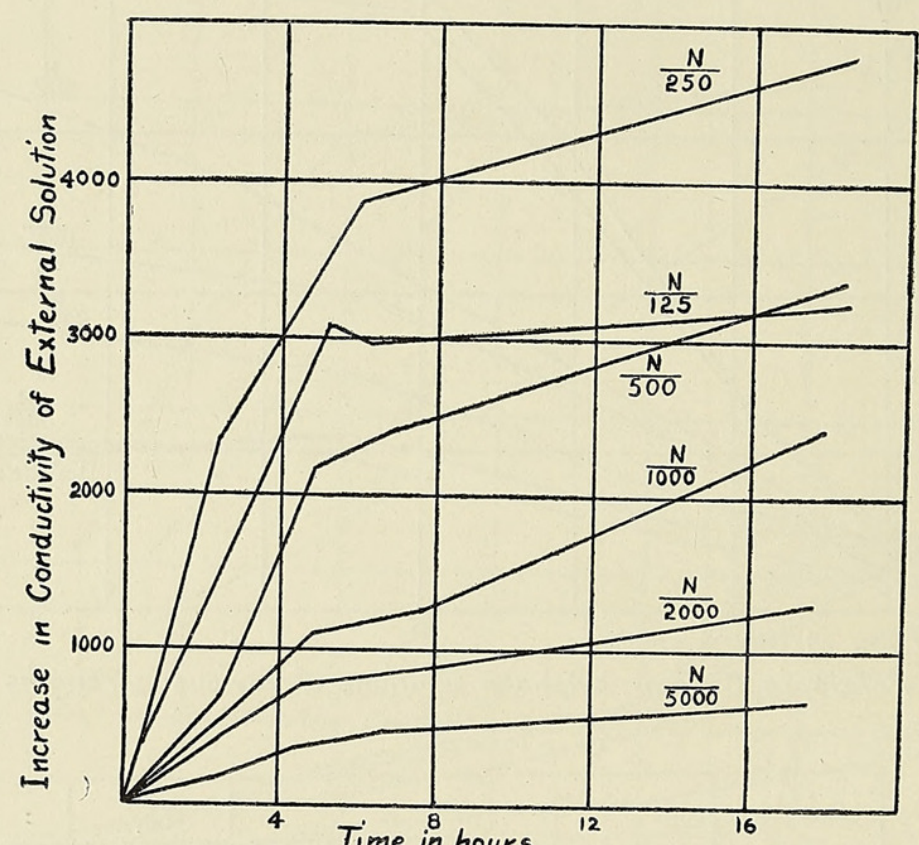

Fig 3 Bean roots in copper sulphate solutions of various strengths

Series 4. A series of measurements was made in which potato discs were immersed in various strengths of a solution of lithium chloride. The salt used was manufactured by Merck. The concentrations employed were as follows : $\frac{\mathrm{N}}{\mathrm{I} 25}, \frac{\mathrm{N}}{250}, \frac{\mathrm{N}}{500}, \frac{\mathrm{N}}{1000}, \frac{\mathrm{N}}{2000}, \frac{\mathrm{N}}{5000}$. Although the rise in conductivity of the solution was not so great as in the case when copper sulphate was used, the general result was the same (cf. Fig. 4).

Series 5. If the exosmosis of electrolytes from living tissue indicated by the experiments described in the preceding series is caused by the formation from the plasma membrane of substances completely permeable to the electrolytes which diffuse out, it would seem possible that, if the rise of conductivity is regarded as a measure of the extent of exosmosis of electrolytes, we might have here a criterion of antagonism. For if another substance be added to the toxic one, the exosmosis produced by the latter will be reduced if there is any antagonistic action between the two ions, and if the added kation is one which of itself produces little exosmosis, the result should be that in the mixed solution the conductivity will increase at a slower 
Stiles and Forgensen.-Studies in Permeability. I. 357

rate than in the pure solution of the salt, its concentration being the same in the two solutions.

In order to test this possibility various mixtures of lithium chloride with potassium chloride were used. In each case the lithium chloride was

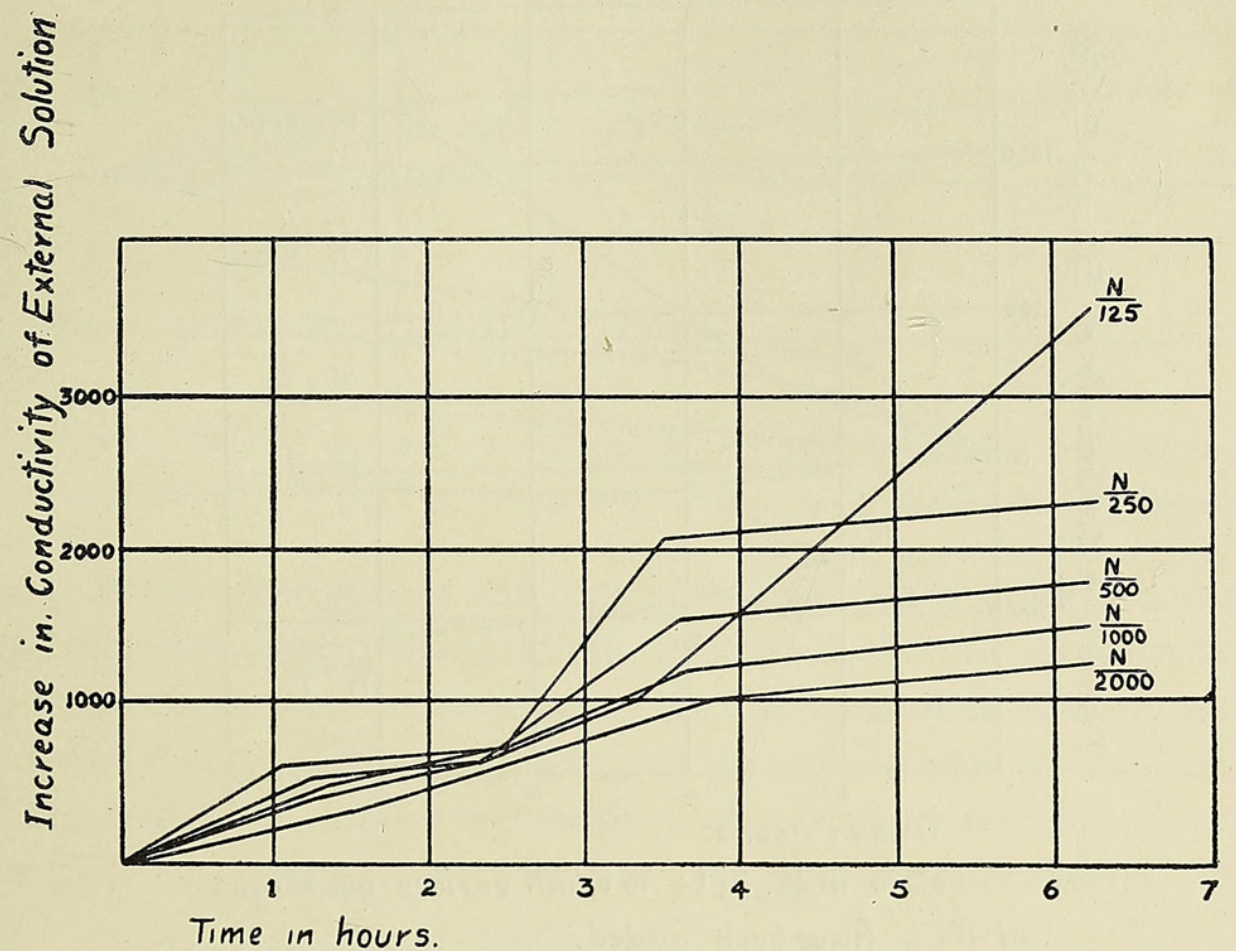

Fig. 4. Potato in solutions of Lithium Chloride of various strengths.

present in the solution in a concentration of $\frac{\mathrm{N}}{2000}$. Potassium chloride was added to the different solutions so that the following ratios of $\mathrm{Li}: \mathrm{K}$ were obtained :

$$
\begin{aligned}
& \text { I }: 0.4 \\
& \text { I }: I \\
& I: 2 \\
& I: 4 \\
& \text { I }: 7 .
\end{aligned}
$$

The curves in Fig. 5 show very clearly how increasing the quantity of potassium chloride decreases the exosmosis produced by the lithium salt, and this is the more striking as a certain amount of exosmosis does result when potassium chloride is present alone in the solution (cf. Fig. I). The result can scarcely be due to a depression of the ionization of lithium chloride as a result of addition of potassium chloride. The strongest solution contains a total number of molecules corresponding to no stronger a solution than one of $\frac{\mathrm{N}}{125}$, and in this dilution nearly the whole of the dissolved substance will be ionized. Also the slowing of the rate of increase 
$35^{8}$ Stiles and Forgensen.-Studies in Permeability. I.

in the conductivity is quite definite in the weakest strength, corresponding to a total concentration of $\frac{\mathrm{N}}{1430^{\circ}}$. The results obtained do seem to indicate an antagonism between lithium and potassium ions, in the sense that the

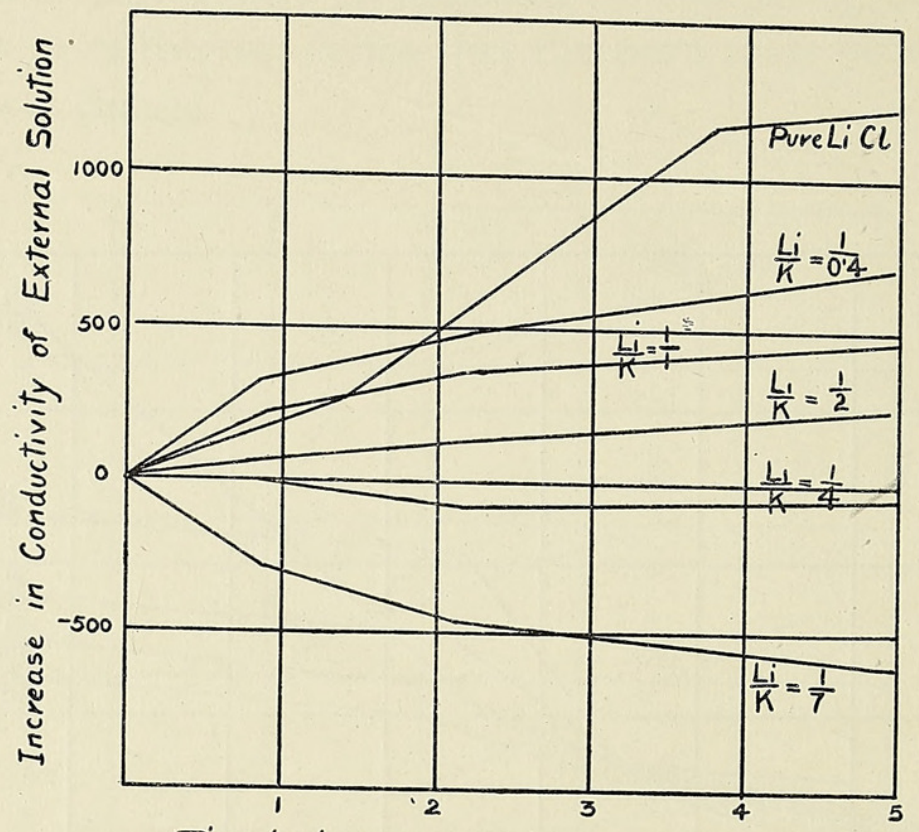

Time in hours.

Fig.5. Potato in $\frac{N}{2000} \mathrm{LiCl}$ to which various quantities of $\mathrm{KCl}$ have been 'added.

exosmosis produced by the lithium salt is reduced in the presence of the potassium salt of the same acid.

Series 6 and 7. As it has been suggested that antagonistic action is

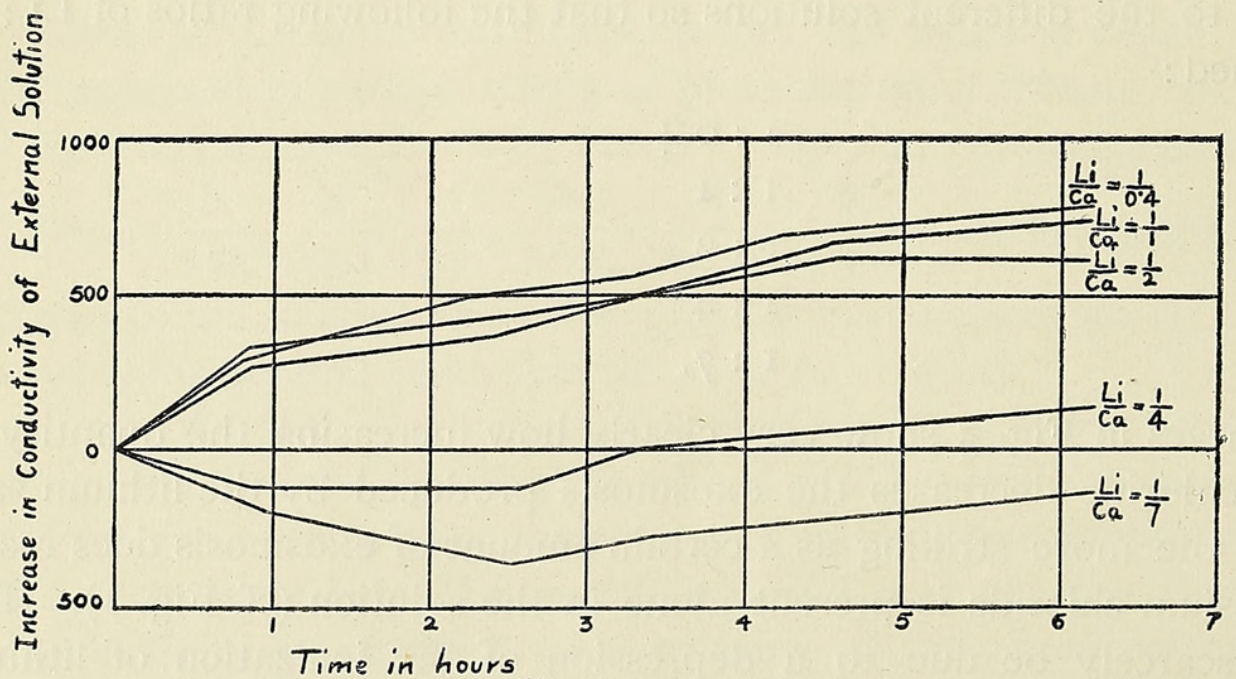

Fig.6. Potato in solutions of $\frac{\mathrm{N}}{2000} \mathrm{LiCl}$ to which various quantities of $\mathrm{Ca} \mathrm{Cl}_{2}$

have been added. The ratios are given in terms of normal, not molecular quantities.

influenced by the valency of the antagonizing ion (9), similar series were tried in which solutions of lithium chloride of the same strength as that used in the last series were used in conjunction with various amounts of 
calcium chloride and aluminium chloride. The kations of both these salts are generally regarded as comparatively harmless ions. The results obtained were similar to those obtained in the mixtures of lithium and potassium chloride, but the results were less rather than more marked. It should be

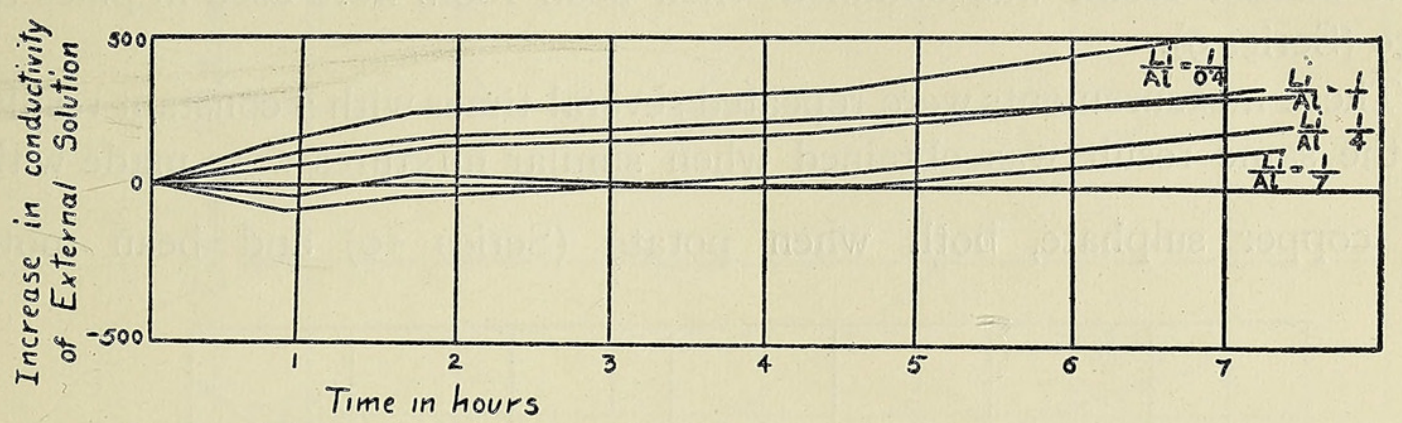

Fig 7. Potato in solutions of $\frac{\mathrm{N}}{2000} \mathrm{LiCl}$ towhich have been added various quantities of $\mathrm{AlCl}_{3}$ The ratios are given in terms of normal, not molecular solutions

noted that the strengths of calcium and aluminium chlorides are given in normal, not molecular concentration. Practically identical results are obtained in all these cases when molecular ratios are used instead of normal ones.

Series 8-II. The antagonistic action of aluminium chloride on copper sulphate had been made the subject of a very interesting investigation of Szücs (25). In order to see whether any similar results would be indicated

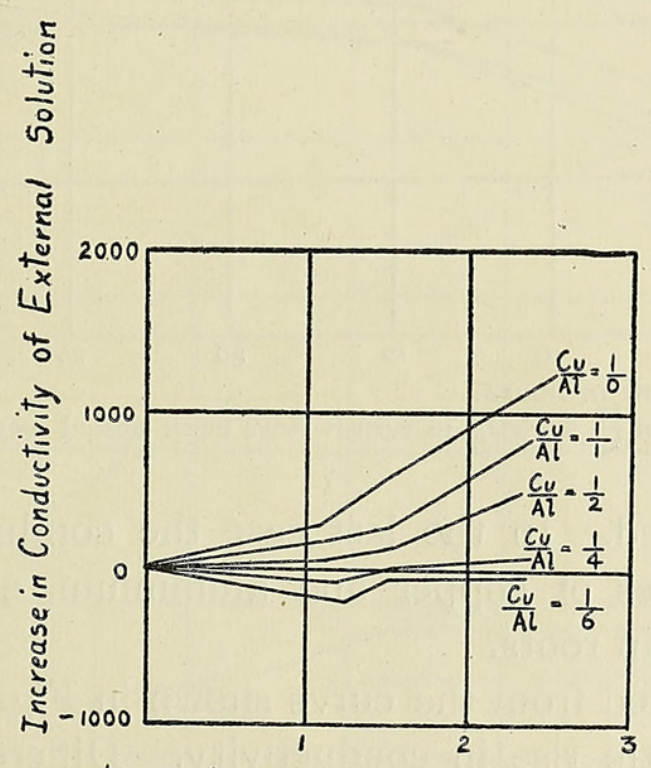

Time in hours

Fig. 8. Potato in $\frac{\mathrm{N}}{1000} \mathrm{CuSO}_{4}$ solutions to which various quantities of $\mathrm{Al} \mathrm{Cl}_{3}$ have been added

by this electrical conductivity method, the effects of mixtures of copper sulphate $\frac{\mathrm{N}}{\mathrm{IO0O}}$ with different quantities of aluminium chloride were examined with potato tissue. The relative quantities of $\mathrm{CuSO}_{4}$ to $\mathrm{AlCl}_{3}$ in the different solutions were $I: 0, I: I, I: 2, I: 4$, and I:6. During the first 
three hours the different solutions behaved very differently, as indicated by the curves in Fig. 8. The more aluminium chloride present, the greater the apparent depression of the exosmosis, so that in the solutions containing most aluminium there is at first a fall in conductivity.

A similar result was obtained when bean roots were used in place of potato (Series 9).

These measurements were repeated several times with a constant result, and the same result was obtained when similar mixtures were made with $\frac{\mathrm{N}}{2000}$ copper sulphate, both when potato (Series I0) and bean roots

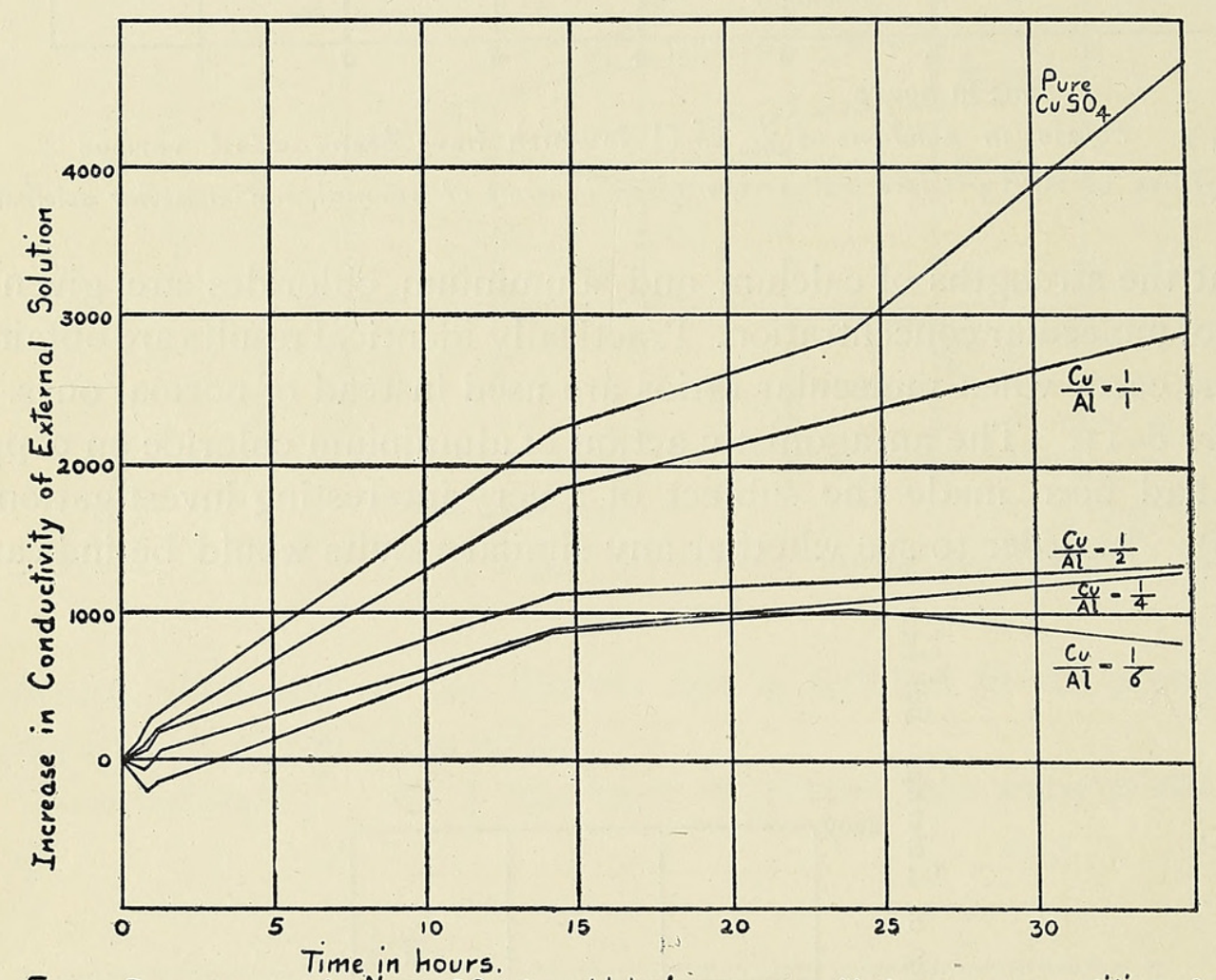

Fig.9. Bean roots in $\frac{N^{1000}}{\mathrm{CuSO}_{4}}$ to which have been added various quantities of $\mathrm{AlCl}_{3}$

(Series II) were used. In the last case the conductivity had risen very little in the mixtures of copper and aluminium, even after forty hours' immersion of the bean roots.

As will be noticed from the curve shown in Fig. I, aluminium chloride itself produces a little rise in conductivity. Different strengths give little difterence in this respect.

At first sight it would appear, then, that by this method a definite antagonism between copper and aluminium is exhibited. This may be the explanation of the results obtained, but, as the next series will indicate, other explanations are possible.

Series I2. A series similar to the last was made with potato in copper sulphate $\frac{\mathrm{N}}{2000}$ solution, to which was added various strengths of ferric 
Stiles and Forgensen.-Studies in Permeability. I. 36I

chloride (Merck's reagent). In water solution ferric chloride gradually hydrolyses into ferric hydroxide and hydrochloric acid. Controls were therefore used of solutions of the same composition but in which potatoes

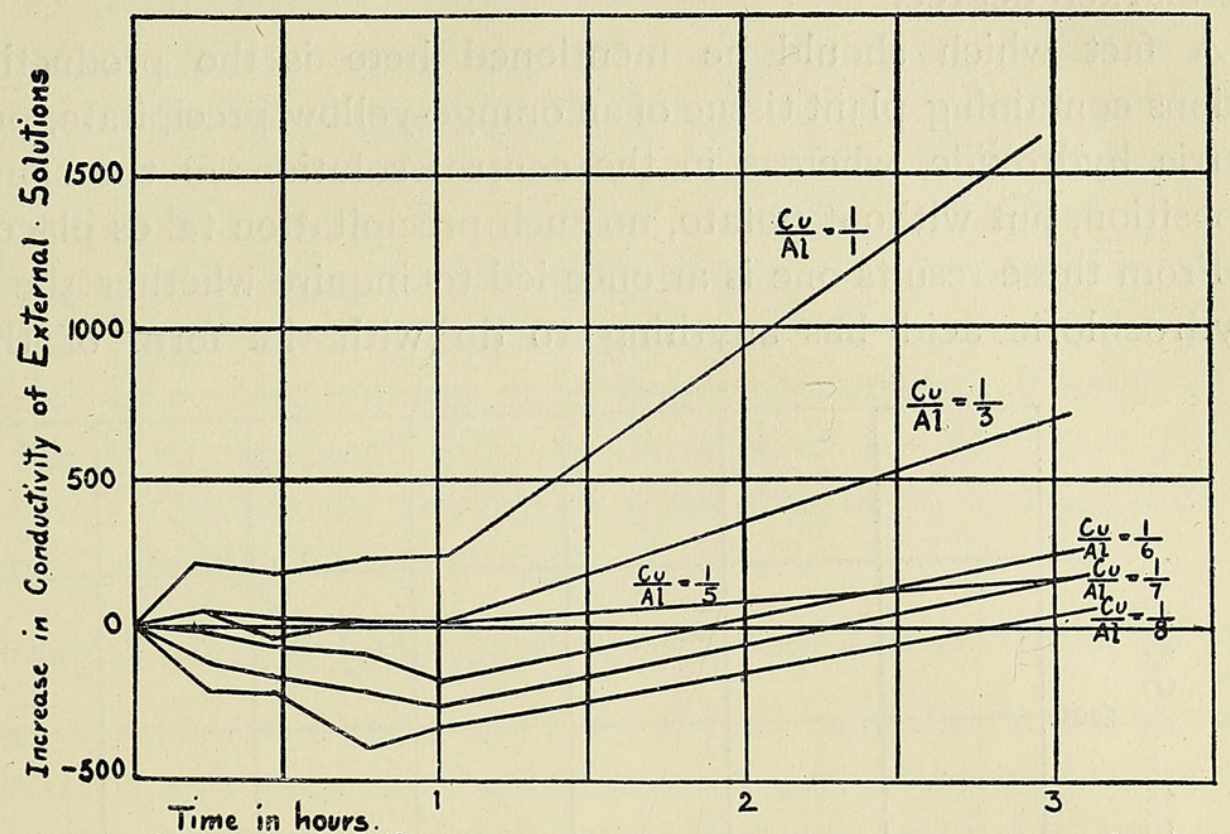

Fig 10. Potato in Mixtures of $\frac{\mathrm{N}}{2000} \mathrm{CuSO}_{4}$ with various added amounts of Aluminium Chloride

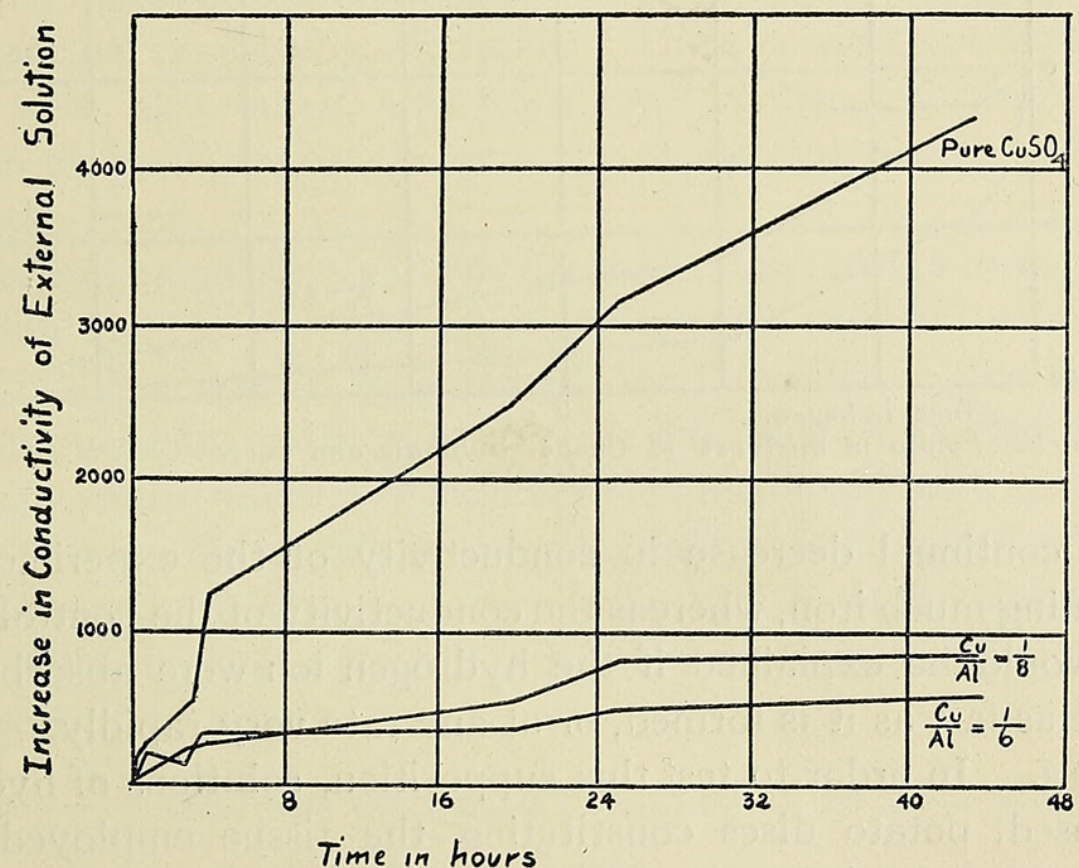

Figil. Bean roots in $\frac{\mathrm{N}}{2000} \mathrm{CuSO}_{4}$ solution and in mixtures of $\frac{\mathrm{N}}{2000} \mathrm{CuSO}_{4}$ with $\mathrm{AlCl}_{3}$.

were not placed. Allowing for the rise in conductivity which takes place in these solutions owing no doubt to the production of hydrogen ions, and which is considerable in the solutions containing ferric chloride in greatest amount, the curves representing the results obtained are as shown 
in Fig. I2. It will be observed that as ferric chloride is added to the copper sulphate the conductivity of the solution is lowered as in the case of mixtures of copper sulphate and aluminium chloride, but in a very much more marked degree.

A fact which should be mentioned here is the production in the solutions containing plant tissue of an orange-yellow precipitate, presumably of ferric hydroxide, whereas in the control solutions of the same original composition, but without potato, no such precipitation takes place.

From these results one is at once led to inquire whether the formation of hydrochloric acid has anything to do with the form of the curves.

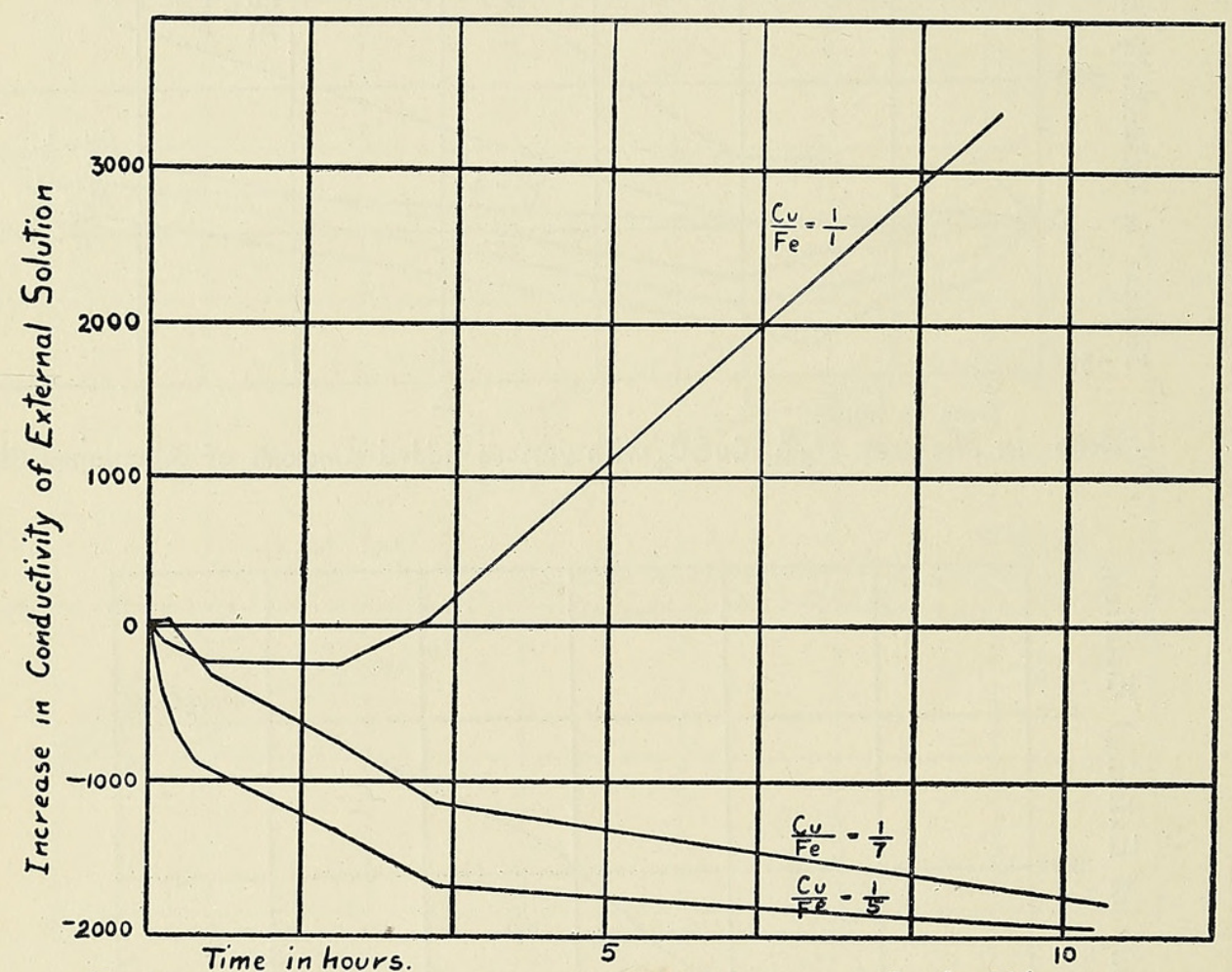

Fig12 Potato in mixtures of Copper Sulphate and Ferric Chloride

We note a continual decrease in conductivity of the experimental solutions containing much iron, whereas the conductivity of the control increases. The result would be explained if the hydrogen ion were absorbed by the plant almost as fast as it is formed, or at any rate very rapidly.

Series I3. In order to test this supposition, solutions of hydrochloric acid were used, potato discs constituting the tissue employed. It was found that a rapid fall in conductivity took place in all the concentrations used $\left(\frac{\mathrm{N}}{\mathrm{I} 00}\right.$ to $\left.\frac{\mathrm{N}}{\mathrm{I} 6000}\right)$. The curve for the case of $\frac{\mathrm{N}}{\mathrm{I000}} \mathrm{HCl}$ is shown in Fig. I3.

Other acids yield similar results. The rapid fall in conductivity of the solution seems therefore due to the rapid absorption of the hydrogen ion by the plant tissue. 
Stiles and Forgensen.-Studies in Permeability. I. 363

With alkalies a similar phenomenon is observed. Sodium hydrate in various concentrations from $\frac{\mathrm{N}}{250}$ to $\frac{\mathrm{N}}{2000}$ has been used, and a fall in conductivity of the external solution has resulted, as in the case of acids.

In order to obtain more definite information as to absorption of acid by plants we have measured the actual change in the concentration of the hydrogen ion by the use of the hydrogen electrode. It is well known that the contact E.M.F. between a metal and a solution of one of its salts is dependent upon the concentration of the ions of the metal in the solution, and the same applies to hydrogen and acids. A considerable time was spent in trials of numerous forms of hydrogen electrodes. Finally we have adopted the platinum-point form recommended by Michaelis (13) and Walpole (26). This has the advantage of enabling rapid work, and gives all the accuracy necessary for our purpose.

The E.M.F. of the hydrogen-electrode was measured against an $\frac{\mathrm{N}}{\mathrm{IO}}$ $\mathrm{KCl}$ calomel electrode, a solution of $3.5 \mathrm{~N} \mathrm{KCl}$ being used as intermediate liquid. Kahlbaum's potassium chloride with certificate of guarantee was used, and the mercurous chloride and mercury used for the calomel electrode were specially purified.

By this method of investigation it was found that the hydrogen ion is indeed absorbed rapidly by the tissue. The electrical conductivities of the solutions were also taken, and from the two sets of results it becomes possible to form an idea of the quantity of electrolytes which have diffused out from the plant.

An attempt was also made to determine the change in concentration of the chlorine ion by the use of the electrode chloride solution-calomelmercury, but the results so obtained are not reliable, for the change in E.M.F. produced by addition of chlorine ions in such an electrode is due to a depression of the number of mercury ions in contact with mercury, and so anything which diffuses out of the plant and can cause a depression of the mercury ions will produce a change in the E.M.F. of the electrode.

The following example will indicate the extent to which the hydrogen ion is absorbed by plants:

Pure $\frac{\mathrm{N}}{\mathrm{I} 000} \mathrm{HCl}$ was used with potato as in the preceding experiments. The conductivity and concentrations of hydrogen ions of the solutions were measured at various intervals of time. For each pair of measurements two sets of potato discs and solution were used, and conductivity and hydrogen ion concentration of both were measured. The following table gives the results obtained by this means. The results are illustrated graphically in Fig. I3.

We do not propose to give here further data regarding the very impor- 
tant question of the permeability of plant tissue to the hydrogen ion, as more detailed investigations of this are at present in progress in this laboratory.

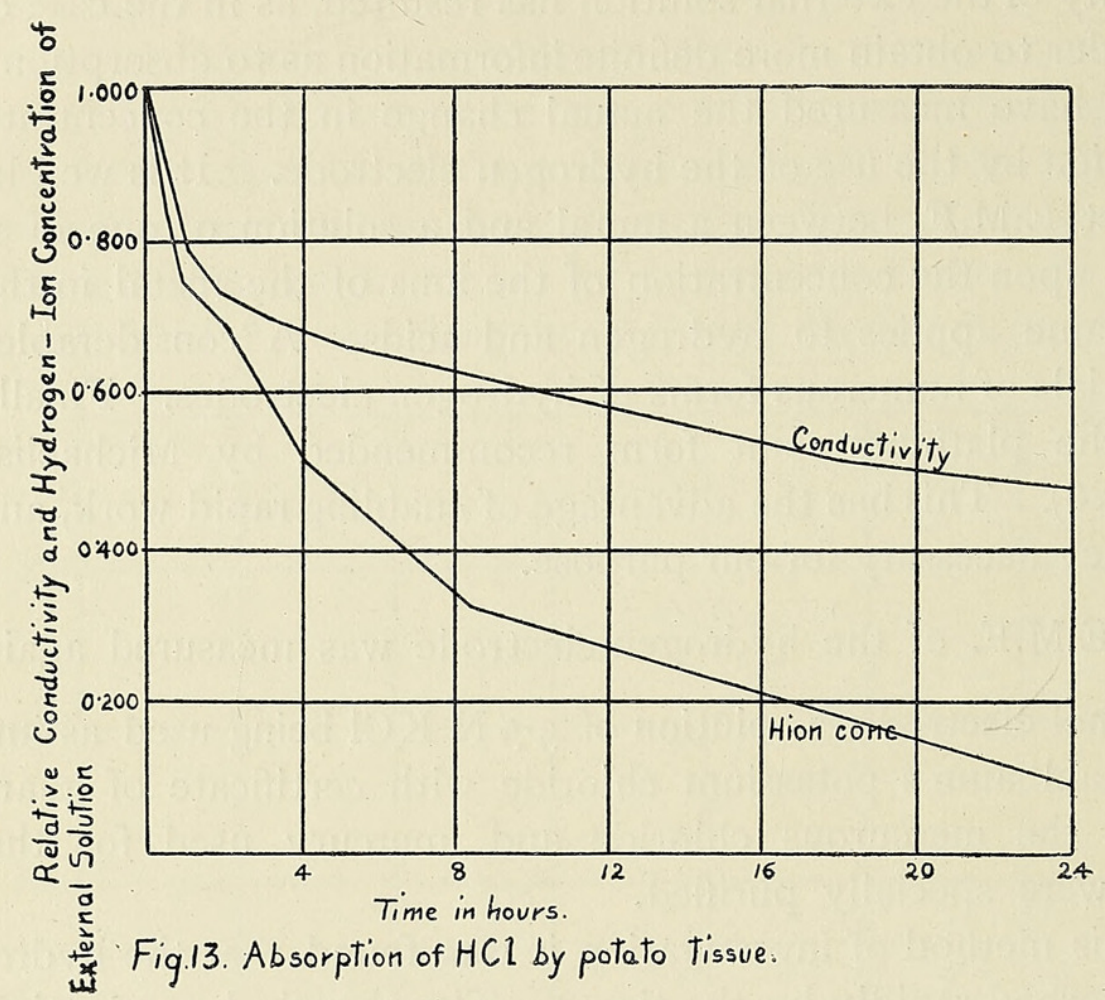

Absorption of Hydrogen Ions by Potato Tuber from $\frac{\mathrm{N}}{\mathrm{IO00}} \mathrm{HCl}$.

\begin{tabular}{|c|c|c|}
\hline Time in hours. & $\begin{array}{l}\text { Strength of Acid in } \\
\text { terms of } \frac{\mathrm{N}}{\mathrm{I000}} \mathrm{HCl} .\end{array}$ & $\begin{array}{c}\text { Conductivity; that of } \frac{\mathrm{N}}{1000} \\
\text { being taken as unity. }\end{array}$ \\
\hline 0.0 & $1 \cdot 000$ & $I \cdot 000$ \\
\hline 0.5 & 0.821 & \\
\hline $1 \cdot 0$ & 0.762 & $0.7^{86}$ \\
\hline $2 \cdot 0$ & 0.7 II & $0.74^{2}$ \\
\hline $3 \cdot 0$ & & 0.711 \\
\hline $4 \cdot 0$ & $0.5^{12}$ & \\
\hline $\begin{array}{l}5^{\circ} 0 \\
9 \cdot 0\end{array}$ & 0.319 & 0.000 \\
\hline $18 \cdot 0$ & & $0.53^{I}$ \\
\hline 34.0 & $0.09^{2}$ & 0.504 \\
\hline
\end{tabular}

\section{Discussion.}

From the results of the experiments recorded above, it seems reasonable to conclude that a diffusion of electrolytes between the inside of plant tissue and the external solution through the cell membranes is a general phenomenon. In our experiments we have dealt mainly with comparatively dilute solutions, and generally here the exosmosis has exceeded the move- 
ment of the ions in the reverse direction. When strong solutions are used, an excess of endosmosis is to be expected. This we have observed ourselves with potato tissue when immersed in strong solutions $\left(\frac{N}{5}\right)$ of sodium chloride and calcium chloride and of mixtures of the two.

Although in dilute solutions of equal strength the relative amount of exosmosis might be regarded as a measure of toxicity, it cannot be assumed that the curves of conductivity of the external solution can so be considered. However suggestive they may be in this respect, it is necessary to remember the complexity of action possible in the solution. The different rates of absorption of different ions and the diffusing out of substances from the plant which react with the external solution are both possible phenomena. As regards the second of these we may cite the case of ferric chloride, in which there results in the external solution conditions which cause the precipitation of ferric hydroxide, while in the control solutions of the same composition no such precipitation takes place. In solutions containing ferric chloride also, the rapid absorption of the hydrogen ions present no doubt influences the conductivity curve exceedingly. It is possible that the same explanation may account for the apparent antagonism between copper and aluminium indicated by the conductivity curves of solutions containing both these ions. No such explanation seems possible of the results in the case of mixtures of lithium with potassium and calcium, but in view of the facts of the case of copper and iron mixtures, we feel that some other reason may account for the form of the curves rather than the apparent one of an antagonism between the two metallic ions.

Nevertheless we feel the results obtained by the method here used suggest a means of obtaining much information relative to the relations between the electrolytes in the cell, the cell membranes, and the external solution. Having regard to the different results obtained in different cases, it is evident that each case will have to be worked out separately. It seems, moreover, quite probable that the different cases of antagonism so far recorded are due in many instances to different underlying causes.

As far as our experiments go, there appears to be no qualitative difference between the behaviour, in respect to permeability to electrolytes, of slices of potato tuber and the roots of uninjured bean plants. This suggests that the methods are suitable for general use, and that general permeability phenomena are being dealt with.

It becomes clear from the experiments here described that the processes involved when plant tissue is immersed in a solution of one salt or a mixture of salts are complex. It thus seems to us that many of the generalizations that have been made by earlier writers, often from single cases, are premature. For example, Osterhout finds that when tissue 
of Laminaria saccharina is placed in a solution of $0.5^{2} \mathrm{~N} \mathrm{NaCl}$, which has a conductivity equal to that of sea-water, the conductivity of the tissue rises with time approximately according to a simple exponential relation. From this he concludes that the change in permeability is due to a change of some substance in the protoplasm, either by a catalytic action of the sodium chloride, or by a reaction with sodium chloride in which very little of the salt is used. He states that a study of the temperature coefficient (a rise of $10^{\circ} \mathrm{C}$. more than doubles the rate of reaction) shows that diffusion of sodium chloride inwards and other salts outwards is not the determining cause of the progress of the reaction. But, as our experiments show, with an increase in permeability there is necessarily an increased rate of diffusion through the cell-membrane, which will of itself produce conductivity changes in the tissues. Moreover, when we are dealing with a complex system such as this, the results obtained at different temperatures require careful analysis, before conclusions as to the nature of the processes taking place can be drawn from them.

Because the plant cell is able to absorb inorganic salts Osterhout holds with Loeb and Pauli that the plasma membrane is protein in nature rather than lipoid, and that the Quincke-Overton theory is untenable. But while it is now generally realized that the plasma membrane cannot be wholly composed of lipoid substances, there is not at present evidence justifying the assumption that it is protein. The cell membrane is one of the most important structures of the cell in regard to its life, and it seems reasonable to suppose that its structure is correspondingly complex. In any case a great deal more experimental work in regard to the permeability of the cell to substances necessary for the ordinary life of the plant is required, before the materials will be obtained for putting forward any satisfactory theory as to the nature of the cell membranes.

\section{SUMMARY.}

The exosmosis of electrolytes from plant tissue has been examined in relation to the composition of different external solutions by means of physical chemistry methods. Within certain limits it seems reasonable to conclude that the rate of exosmosis is a measure of toxicity. A decrease in this rate when certain ions are added to solutions containing undoubtedly poisonous ions might be due to the same cause that produces what other investigators have called antagonism. In some instances we have shown that the phenomena are more complex than are generally assumed. We have emphasized the necessity of examining and analysing each case separately. The use of the methods of physical chemistry indicate the possibility of obtaining more definite information of the laws governing the exchange of substances between the interior and exterior of the cell.

Botany Department,

The University, Leeds,

February 27, 1915. 


\section{LiteRATURE CITED.}

1. Beutner, R.: Die physikalische Natur bioelektrischer Potentialdifferenzen. Bioch. Zeitschr., Bd. xlvii, I9I2, pp. 73-96.

2. : New Galvanic Phenomena. Amer. Journ. Physiology, vol. xxxi, I9r3, p. 343.

3. - Neue Erscheinungen der Elektrizitätserregung, welche einige bioelektrische Phänomene erklären. Zeitschr. für Elektrochemie, Bd. xix, 1913, pp. 319-467.

4. Cameron, F. K.: The Soil Solution. Easton, Pa., I9i I.

5. Cranner, B. Hansteen : Über das Verhalten der Kulturpflanzen zu den Bodensalzen. III. Beiträge zur Biochemie und Physiologie der Zellwand lebender Zellen. Jahrb. für wiss. Bot., Bd. liii, I9I 4, p. 536.

6. Hawkins, L. A. : The Influence of Calcium, Magnesium, and Potassium Nitrates upon the Toxicity of certain Heavy Metals towards Fungus Spores. Physiol. Researches, vol. i, I913, pp. 57-92.

7. HöвеR, R.: Ein zweites Verfahren, die Leitfähigkeit im Innern von Zellen zu messen. Arch. f. die ges. Physiologie, Bd. cxlviii, I9I 2, pp. I 89-22 I.

8. : Messungen der inneren Leitfähigkeit von Zellen. Dritte Mitteilung. Ibid., Bd. 1, I9I 3, pp. I 5-45.

9. Loeb, J.: The Dynamics of Living Tissue. New York, I906.

10. Loeb, J., and Beutner, R.: On the Nature and Seat of the Electromotive Forces manifested by Living Organs. Science, N. S., vol. xxxiv, I9I I, p. 884 .

11. __ : Die Bedeutung der Lipoide für die Entstehung der bioelektrischen Potentialdifferenzen bei gewissen pflanzlichen Organen. Bioch. Zeitschr., Bd. li, I9I3, p. 288 .

12. : Einfluss der Anaesthetica auf die Potentialdifferenz an der Oberfläche pflanzlicher und tierischer Gewebe. Bioch. Zeitschr., Bd. li, I9I3, p. 300.

13. Michaelis, L. Bioch. Zeitsch., Bd. xlvi, I9I2, p. I3I.

14. Osterhout, W. J. V.: On the Importance of Physiologically Balanced Solutions for Plants. II. Fresh-water and Terrestrial Plants.' Bot. Gaz., vol. xliv, I907, p. 259.

15. : The Permeability of Protoplasm to Ions and the Theory of Antagonism. Seience, N. S., vol. xxxv, I9I2, p. II 2.

16. : Some Chemical Relations of Plant and Soil. Science, N. S., vol. xxxvi, I9 12, pp. 57 I-6.

17. : The Chemical Dynamics of Living Protoplasm. Science, N. S., vol. $x x x i x$, I I $_{4}$, pp. 544-6.

18. $:$ Quantitative Criteria of Antagonism. Bot. Gaz., vol. lviii, I9I4, pp. $\mathbf{1} 78-86$.

19. : The Measurement of Antagonism. Bot. Gaz., vol. 1viii, I9 I4, pp. 272-5.

20. : The Forms of Antagonism Curves as influenced by Concentration. Bot. Gaz., vol. lviii, I9I4, pp. 367-7I.

21. I9I4, pp. 488-9I.

22. Stiles, W.: On the Relation between the Concentration of the Nutrient Solution and the Rate of Growth of Plants in Water Culture. Ann. of Bot., vol. xxix, I9I5, pp. 89-96.

23. Stiles, W., and Jergensen, I. : The Measurement of Electrical Conductivity as a Method of Investigation in Plant Physiology. New Phytologist, vol. xiii, I9I4, pp. 226-42.

24. Plants. New Phytologist, vol. xiii, I9I4, pp. 253-68.

25. Szücs, J. : Experimentelle Beiträge zu einer Theorie der antagonistischen Ionenwirkungen. I. Mitteilung. Jahrb. für wiss. Bot., Bd. lii, I912, pp. $85^{-1} 4^{2}$.

26. Walpole, G. S.: Gas Electrode for general use. Biochemical Journal, vol. vii, I9I3, pp. 4I0-28. 

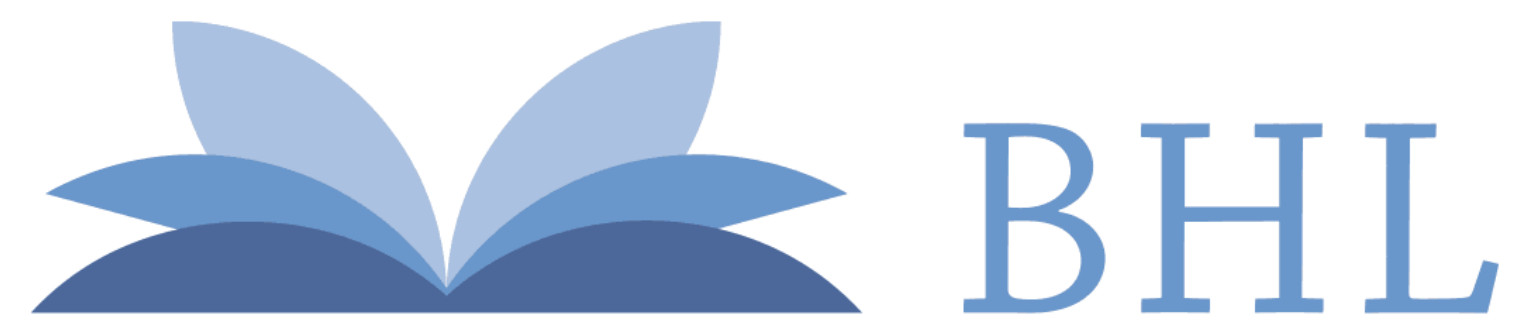

\section{Biodiversity Heritage Library}

Stiles, Walter and Jorgensen, Ingvar. 1915. "Studies in permeability. I. The exosmosis of electrolytes as a criterion of antagonistic ion-action." Annals of botany 29, 349-367. https://doi.org/10.1093/oxfordjournals.aob.a089552.

View This Item Online: https://www.biodiversitylibrary.org/item/243629

DOI: https://doi.org/10.1093/oxfordjournals.aob.a089552

Permalink: https://www.biodiversitylibrary.org/partpdf/320069

\section{Holding Institution}

Smithsonian Libraries

\section{Sponsored by}

Biodiversity Heritage Library

\section{Copyright \& Reuse}

Copyright Status: Not in copyright. The BHL knows of no copyright restrictions on this item.

This document was created from content at the Biodiversity Heritage Library, the world's largest open access digital library for biodiversity literature and archives. Visit BHL at https://www.biodiversitylibrary.org. 